\title{
乳房炎の化学療 法
}

\section{IV. ぶぞら球菌症に対するオーレオマイシンおよびマイシリンの效果}

\section{吉田信行* 桐沢 統* 天野・毅** 萐清知彥*}

前回 ${ }^{209}$ は Streptococcus agalactiae 以外の連鎖球菌 (以下連菌) Str. bovis, Str. faecalis およびStr. uberis 等の主にぶどう球菌 (以下ぶ菌) との混合感染症の牛の 乳房炎の治療について報告したが，今回住慢性ぶ菌性乳 房炎に対するオーレオマイシン（以下オマ）扰よびマイ シทンの治療効果について記載することとした。

オマについては MCCoLLOCH, KISER \& MIGAKI ந6) がぶ菌性乳房炎に試み, その洒值を推賞して以来S SAALM 9) の反対毛市ったが，EASTERBRoOKs2) 特よび Slanetz \& ALLEN ら13) るとの卓越した效果を認めた。 SLANETz \& ALLEN らは $200 \mathrm{mg}$ 含有軟膏の 3 回淮大によって連菌 症に括いては 100\%，ぶ菌症に执いては96.1\%の治験率 を㐫げたが，SPENCER，KRAFT，S SMON \& SCEENK14)は 連菌症に站してはペニシリンの方がやや良好であるとい った。ぶ菌に詨して現在まで慢性症に沶いて欧米で他の 抗生物筫や，これとサルファ用との混注療法の治癒率が わずかに20〜70\%前後であり，゙われわれの成績子これら の間の成績えようやく収めえたにすぎなかったのに比 較し,Slanetz \& ALLEN らの結果は極めて優秀である ことがわかる。

マイシソンがぶ菌性乳房炎の治療効果の期待できる ことは FOLEY \& BRYNe3), COOPER, FORD \& ROBINSON 5 1), Schipper 11),-SchalM \& WoODS 5 10) によって証 明せられ，SCHALM は特に搾乳中の牛に大量の使用を奖

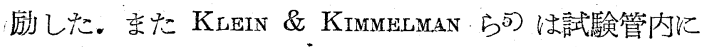
敃いてマイシリンに対してては菌は耐性獲得が和そい上に 雨抗生物筫は協同作用を発揮することを認めた。

\section{実 験 成 樍}

治療に供した牛は農業技術研究所蒙畜部，千葉市外旭 村および新潟県杊羽郡の農蒙と当場の牛趜18頭, 42 分房 でこの5ち6頭，10分房はオマおよびマイシリン相再 の間で転換療法の試験を行った。

抗生物質は乳量に関係なく，オマは武田薬品工策の供 試品レダリー会社製の乳房炎専用チューブ大軟膏 $(7.5 \mathrm{~g}$. オマ $420 \mathrm{mg}$ 含有)，われわれの作ったラノッン，流動パ ラフィン，カーボワックス $(1,500) 10 \mathrm{~g}$ を基剤とした $200 \mathrm{mg}$ 含有軟滈和よび $200 \mathrm{mg}$ 含有溶液 (隇菌蒸溜水 $50 \mathrm{cc}$ ) を48時間每に前者の久は 3 回，他の 2 者は 2 回い

\footnotetext{
* 農林省家畜衛生試験場北陸支場

**网山県草間家畜保健衛生所
}

ずれも控孚值後，われわれの考案した導乳管兼用の乳房 炎用注大管を使用して直接注大法を行った。マイシリン は笑嗝当初枋販品がなかったので，第 5 拈よび第 6 表に あるよ5に，適宜の比率汇両者を配合し滅菌蒸溜水 $50 \mathrm{cc}$ に溶解，オマと同様乳量を顧慮することなく 1 日 1 回 2 回注大した。市販品が出るに支んで明治（結晶プロカイ ンペニシリンG30万単位，緩衝結晶ペニシリンGカリウ ム塩10万単位，結晶デヒドロストレプトマイシン硫酸塩 $0.5 \mathrm{~g})$ 觉用い, 最初全量を $2 \mathrm{cc}$ 隇菌蒸溜水に溶解し 1 日 1 回との1/4 量（すなわら・゚剂 100,000 単位とストマ イ 125mg）を3 日連続注大した。

乳幦の検查は治療最後の日から $1,2 ， 3 ， 5,7$ 日r その後 1 週間执きに $3 \sim 5$ 週まで行って效果を判定し た. 現在なでの経験によると乳筫の検査は少くとる 3 週 間は必要である、それは效果判定特に扣いて無效々認め られるような慢性症の場合でも，使用された薬物のため 2 週閒位までは一畤細菌の発育も抑制せられ組織の新生 多認められないが，これ以後細菌は再び増殖し白血球も 増生することがあるからである。しかしこの間の再感染 に考慮を払うことの肝要であることはいうまでるない。

\section{1. オマの乳中濃度}

1 日 1 回および 2 回控孚牛についてはレダリー会社の オマ $420 \mathrm{mg}$ 含有軟膏，3回搾乳牛については同社のその 後の製品 $426 \mathrm{mg}$ 含有軟旁々同社の産後内膜炎等の予陏 に用いる子宫坐薬 (500mg含有の錠剤) を減菌蒸溜水を 以て溶解し，50cc 中に才マ $400 \mathrm{mg}$ を含もよ5な溶液を を2 分房宛注大し，前報 20 でも報じたように, オマの 濃度は鳥居，川上ら16) および鳥居, 小島ら 17) によって 溶連菌を用い重冨法に従った。 オマ軟亳の優秀性につい ては最近SCHIPPER \& P ETERSEN ら 12) も指摘した。前報20) と比較し第 1 表の高い濃度は，たんにオマが本試験では

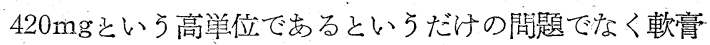

第1表 1 日 1 回和よび 2 回搉乳牛のオーレオマイ シンの乳中濃度

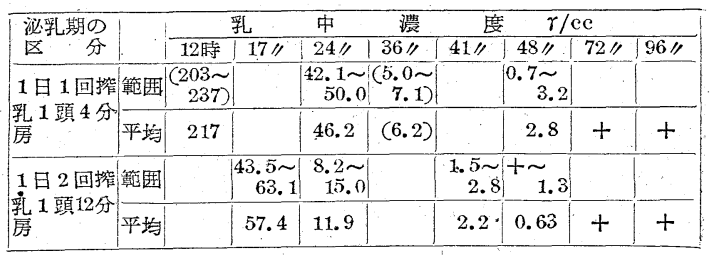

備考：（1） 1 回搾乳牛の12時，36時は毎回 $10 \mathrm{cc}$ あて学とつて検查し F. (2) $+\cdots \cdots \cdot$ 痕䟢 
の優越を示するのであろ5。

われわれの成績はほとんどSCHPPER \& PETERSEN らに 同じようであって，1日 1 回控乳牛( 1 日乳量約 $2.7 \mathrm{~kg}$ ) では 24 時間後 $46.2 \gamma / \mathrm{cc}$ の高濃度を示し，48時間後なお $2.8 \gamma / \mathrm{cc}$ の残留怘不た。 2 回䆣乳牛（1 日乳量約 $4.0 \mathrm{~kg}$ ) 以ついてb注入後 3 回目の管乳に拈いて $2.17 \gamma / \mathrm{cc}, 48$ 時 間後 $0.63 r / \mathrm{cc}$ の濃度を測定することができた。な抗こ の牛は治療にも供したもので48時間隔に 3 回注大を行っ たが，連続注大による残留濃度の間に著しい変化は認め られなかった。

3 回擦乳牛（1日の乳量はわずかに約 $7.4 \mathrm{~kg}$ であっ たが，試験のため 1 日に 3 回搾孚していたもの）のオマ 乳中濃度は第 2 表に示した。水溶液学注大した左前の分

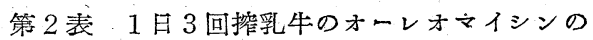
乳中濃度 (単位 $r / \mathrm{cc}$ )

\begin{tabular}{|c|c|c|c|c|c|}
\hline 時間 & 颙 & 裔 & 水 & 性 & \multirow{2}{*}{ 均 } \\
\hline 时阳 & 右 前 & 在 & 左： & 左 & \\
\hline 8 & 255.00 & 125.00 & 255.00 & 187.50 & 205.63 \\
\hline 16 & 18. 75 & 25.00 & 175.00 & 12.50 & 57.94 \\
\hline 24 & 22.20 & 22.00 & .22 .20 & 10.68 & 19.32 \\
\hline 32 & 16.25 & 10.68 & 16.25 & 3.13 & 11.53 \\
\hline 40 & 16.25 & 16.25 & 10.68 & 10.68 & 13.47 \\
\hline 48 & 3.13 & 2.60 & 3.75 & 2.60 & 3.02 \\
\hline 56 & 4.61 & 3.13 & 3.13 & 0.94 & 2.95 \\
\hline 64 & 0.94 & 0.94 & 2.50 & 0.65 & 1.26 \\
\hline 72 & 1.13 & 1.13 & 4.53 & 0.54 & 1.83 \\
\hline 80 & 0.94 & 0.65 & 1.13 & + & 0.68 \\
\hline 88 & 1.13 & 0.54 & 1.13 & 0 & 0.70 \\
\hline 96 & 4 & 0 & + & 0 & + \\
\hline 102 & 0 & 0 & 0 & & 0 \\
\hline
\end{tabular}

房の16時間冒の高い濃度については，いろいろ考察され る点があららが，もともとこの分房は常に乳量が最も少 なかった上，この時には他の 3 分房の $1 / 2 \sim 1 / 3$ の乳量 に達しなかったことが大きい理由であろう．そしてこれ を除けば 4 分房ともに乳中濃度はほとんど近似の洒を示 した。な拉オマの残留時間の趠長と比較的高濃度の持続 とは牛の個体によるものか，乳量が少ないのにかかわら ず 3 回の控乳を強いて行っていたためか，それとも新し い $426 \mathrm{mg}$ 含有軟膏の性状がやや前のものと違っていた ためか，例数が少いので確たる判断を下しえない。

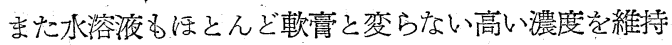
したことは子宫坐薬が扔そらく含有していると想像され るある物質によるものではあるまいか。SCHIPPER \& PETERSEN'b 12 ) の 3 回控孚牛は才マ $400 \mathrm{mg}$ の水溶液注 大後24蛙間では $1 \mathrm{cc}$ 中わずかに<1.0r にすぎなかった。

前述したように 4 分房に同特にオマを注大した際の血 中⿰よび尿中濃度を第 3 袁にあげたが，この程度乳房内 にオマ穵注大すると血液も相当の濃度を示し，6時間で 最高で $0.782 \gamma / \mathrm{cc}$ の值を示し，尿はさらに高濃度を24時

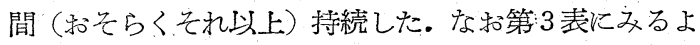
ろに尿を科量して尿中のオマの総量を計算した。本試験 では 8 時間後以降は採尿の間隔が大きく不確笑である
第 3 表オーレオマイシン乳房内注大による血中 和よび尿中濃度

\begin{tabular}{|c|c|c|c|}
\hline 時 間 & 血 中 $r / c c$ & 尿 中 $r / \mathrm{cc}$ & 尿中の総量 $\mathrm{mg}$ \\
\hline 注 入 前 & 0 & 0 & \\
\hline 1 & 0.195 & 0 & \\
\hline 3 & 0.278 & 62.50 & 28.750 \\
\hline 6 & 0.782 & 31.25 & 10.000 \\
\hline 8 & 0.195 & 31.25 & 20.937 \\
\hline 12 & 0.310 & 7.82 & 9.618 \\
\hline 16 & & 10.94 & 7.111 \\
\hline 24 & 0 & 7.82 & 8.132 \\
\hline 48 & & 0 & \\
\hline
\end{tabular}

備考：尿は 10 倍稀釈を用にた。

第 4 表 オーレオマイシンの乳房からの排出量 (単位 $\mathrm{mg}$ )

\begin{tabular}{|c|c|c|c|c|}
\hline $\begin{array}{l}\text { 乳屏区分 } \\
\text { 㩁乳区分 }\end{array}$ & 前 & 右 & 左 & 庄 \\
\hline 2 回㩁乳牛 & 45.027 & 52.570 & 46.968 & 39.780 \\
\hline 3 回摧乳牛 & 121.171 & 143.125 & 150.250 & 113.127 \\
\hline
\end{tabular}

備考： 2 回摧乳牛は各分房とも 3 回検查の平均を示す. が，第4表のオマの牛乳中に排开される量とを合計する と 4 分房に計約 $1,600 \mathrm{mg}$ 注大によって，乳中と尿中と に大略その $38.3 \%$ を排出した結果となった。乳宋の排 出量はへ剤の場合 18 ) と比較し 2 回控乳牛も含めて考察 すると，オマは乳中からの排沽量が少いように思われる がここれは泌乳量に最も大きく支配されるから軽卒に断 定て下しえない。

第 1 执よび第 2 表とから軟膏の場合においてばぶ菌症 の際もそのオマに対する抵抗性からみて，才、感性菌治 療は搾乳回数に区別なく48時間和き注大がやはり理論的 であって目的の濃度を持続するょうである。

\section{2. 治 療 成 績}

オマは前回 20) も報じたように乳腺組織に対する刺激 がや゙や強く，軽度の出血を伴うことがしばしばあった がここレダッー会社の製品も同様で， pH のアルカッ に傾く変化は治療前十，あるいは土程度のものでも治療 後卅, 凝固物試験士, あるいは十が注大後サ〜卅の強さ となって，時に相当大きい凝固物の認められることもあ ったが，この状態は大体 1 週間以内に常態にるどった。 な和出血については 1 頭は 2 回注大後，他の 2 頭は 3 回 注大後いずれも軽度ながらみられたが，2〜3日で出血 はやみ, その後治療による乳量の減退等の悪影響は残ら なかった。

白血球の变動をみると治療效果の優れたるのる無効で あったものも，オマによって治療翌昍 2.7 倍に増殖し た。そして効果のあったものは沿療後 3 日ですでに白血 球数の減少を認め, 治療前平均 $1 \mathrm{cc}$ 中 564,200 の数学 を示したものが， 7 日後598,000，2週間後282,000，3 週間後 236,000 となった。これに反し效果のなかった群 では個体によって治療後 2 ～ 5 日に一時白血球の漸減を 
みたるの子少々なかったが,多くは 7 ～14日頃から再び 白血球の増生汴認められた点はぺ剂その他の薬物の場合 と同様であった。これらの諸点を総合して考えるとオマ の乳腺汇対する刺激は特に強いとも思われない. SCHIP-

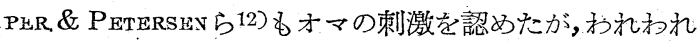
と同じょう汇約 3 日後に白血球は滅少すると発表した。

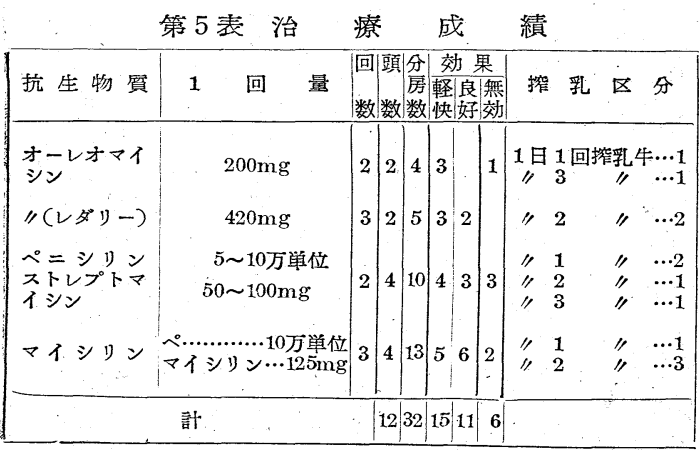

備考：（1）㩁乳区分 1 回㩁乳牛は1 日乳量 2 回.

（2）効果判定の軽快は乳筫㭘查 ( $\mathrm{pH}$ 、凝固物試験，白血球数 $1 \mathrm{cc}$ 中 500,000 以下在陰性とする) に陰性, 細菌数 $1 \mathrm{cc}$ 中 200 以下の 8 の. 良好は乳賀を問わず細菌数 $1 \mathrm{ce}$ 中 500 以下，または乳嘪いずれか 㝜常でも細菌数 $1 \mathrm{ce}$ 中 200 以下のるの. 無効はそれ以外のもの. 次表 る同じ.

第 5 表の 万ち急性症は $200 \mathrm{mg}$ 万、使用の農家の 1 頭, 1 分房のみであって，本分房の乳質はいずれの点からみ て离極めて不良であったが，治療後乳質は全く正常とな り，培養の結果もほとんど無菌に近い成續を示した。こ の急性症を除く之慢性症の相当碩固の 31 分房中乳筫正 常，細菌数 $1 \mathrm{cc}$ 中 200 以下となった軽快例は 14 例 ( 45.2 $\%$ ，良好は 11 例( $35.5 \%)$ ，両者学合せると 31 分房中 25 例，すなわち $80.7 \%$ 1 cc 中細菌数が 500 以内となっ た.マイシリンの無効の 1 分房は農家の牛で乳頭先端に 創算が認められたるので，かつやく筋の驰緩が不全であ るため，た党ず感染の危険にさらされていたるのであっ たから，扣そらく再感染によるるのと考光られる。

次に第 6 表は表示の治療を行 5 前にオマの場合はマイ シリン，マイシリンの場合はオマ治療をそれぞれ試みた がはとんぞ無効であったもので，本転換療法の成績は極 めて不良であった。すなわちこれら抗生物筫間和ける 交叉而性の傾问が少数例ながららかがわれた。この交叉 预性の問題は in vitro に扔いて子他のいろいろの菌に 第 6 表 転 換 療法の成績

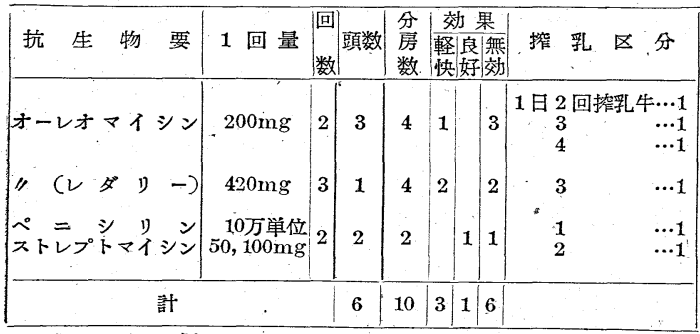

備考：前表と同じ.
ついて証明されているところであるが，ただレダり一会 社製品を以て治療した農家の 1 頭 4 分房は相当長期に方 たって・剂などによる治療に失敗し，われわれが診療究 气われた時は，4 分房共に分離乳で分婏る近かったが： 乾孚高ることのできなかったるのである. 分離菌は抗・ 性強く，2.0u/cc，モナフラシンにる10,000倍沦耐光た

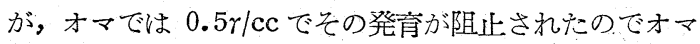
を使用した。その結果 2 分房は軽快したが，他の 2 分 房は細菌数が 1cc 中 500上下とならず，やや良好の成 䥊を示したにすぎなかったので，さらにオ、軟高注入 後,われわれの作った $0.2 \%$ モナフラシン溶液 $25 \mathrm{cc}$ を さらに注大，この療法を48時間执き核 3 回繰返して極め て優秀な効果を奏することができたが，このオマとモナ フラシンとの混注は表示していない。な招，本牛は治療 時すでに初脬に近い牛乳を分泌し始めていて全く乾乳の 期間もなく間もなく分婏，雌の于牛も異状なく育ってい る.

\section{3. 醅母に上る急性乳房炎の 1 例}

分娭後 2 カ月の千葉市外農蒙の飼育牛 (発病前 1 日乳 量約 1 斗, 1 日 2 回搾乳) の 1 分房中に純粋に䤏母（1cc 中31，400）が見出された。この分房は全般にわたって腫 脹，硬結が特に強度で劇痛を訴光，泌孚孔停止し，よう やく $10 \mathrm{cc}$ の検査材料を採取した。乳質は $\mathrm{pH} 7.0$ 前後, 大きい多量の㠜固物を混入し，白血球る無数であったが， 急性であるためこれら乳質検查を行う前てべ剂 100,000 単位とサルゾールS (実量 $3 \mathrm{~g}$ ) とを隇菌蒸溜水で $50 \mathrm{cc}$ として混注，1日 1 回連用 3 日の結果，治療 1 日で乳房

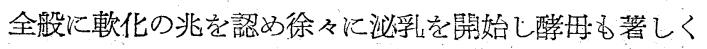
減退 (治療後 3 日で酵母は $1 \mathrm{cc}$ 中 28 亿激減)，数日で 乳房は腫脹, 硬結すほとんど認められなくなり泌孚量も 前にもどった。最後の治療から 23 日目に括ける牛乳検查 の結果 $\mathrm{pH}$ は正常, 凝固物除性, 白血球 $1 \mathrm{cc}$ 中 130,000 で正常, 酵母る全く消失したが, ぶ菌方 1 cc 中 21 存在 した。

䤉母なたはこれに類する微生物沉よる乳房炎は現在ま でK Murphy \& Drake ら 7), Stuart 15), Hutsh 4), Pounden, Amberson \& JAeGerR ら ${ }^{8)}$ にょって報告され

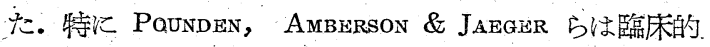
にも詳細に発表した。氏ら挔よび MURPHY \& DRAKE らもいっているょうに：これら酵母はなんらの治療を行 わなくとも自然に消隇することがあるようである。そし

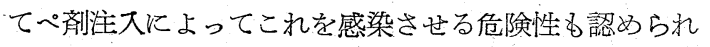
ていてぺ剤には抵抗性が特に強いといわれている。

われわれの䣲母子抗一性は著しく強く,肉测 $(\mathrm{pH} 7.0)$ 中 24 時間で約 $8,000 \mathrm{u} / \mathrm{cc}$ 以下では発育を阻止すること ができない。またサルン゙ールS するためには $10 \mathrm{~g} / \mathrm{dl}$ の高濃度を要求し，またモナフラ

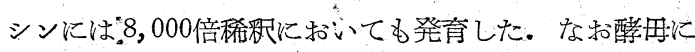


対するぺ剤とサルゾールＳとの協同作用は試験管内におる いては認められなかった。この結果からみると治療に用 いた程度の薬物では，その効果を期待することは困難で あったわけであるが，それにるかかわらず治療後酵冉は 㨁ちに減少を始め, 泌乳を開始したことや，その他の症 状から判断して一面には少く々も薬物の直接効果を否定 することはできないであうう。

\section{考察}

この試験にっいては主としてぶ菌性慢性乳房炎に対す るオマとマイシソンとの效果を比較したが，両者間には 意味のある差異は存在しない上うである。そしてこれら 物質を使用することによって，碩固な慢性症を主とする にもかかわらず，前回 20 の Streptococcus agalactiae 以外のいろいろの連菌性乳房炎の急性症の治療効果にほ ぼ匹敵する良好な成績を収めえた。この事害はたんに薬 物の種類，その使用量だけの問題でなく，一面前報した 連菌単独感染およびこれらとぶ菌との合併症の治療の困 難さを示するのであらう。

この試験と执いては前回と同じょうに少くとも治療後 3 週間,菌が陰性となった分房は 1 例もなく，第I報19) と 異なる点にういては，最近乳牛飼育者が安易溸人療法 を試みる機会も多く，細菌が果してこれら薬物に対して 抵抗性を獲得したるのか，または効果の観察期間中再び

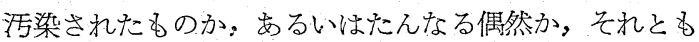
他の原因によるものか全くわれわれは判断代苦しむるの である。

第】報汇報じたように，ら゙菌純料感染の慢性症に対ず る治療効果は著効々軽快とを合せ，べ斉とサルフォ剤の 場合 $36.4 \%$ ，フラン系誘導体の場合 $42.1 \%$ ，さらにこれ に良好を加兑るとそれぞれ $59.1 \%$ ，68.4\%であったが， 今可の成績はオマとマイシリンとを合せて軽快 $45.2 \%$ ， 良好を加光ると $80.7 \%$ ，いずれにしてるこれら抗生物 賀の卓越性がうかがわれるであらう。

転換療潜を行らたオマとマイシリンとの間にはぶ菌の 交叉耐性獲得の傾向が認められた. 特にマイシリン療 法後8〜11 日後にオ、水溶液を以て再治療を試みた 3 頭，3分房についてはオマの薬効を全く認めることはで きずこのうち 2 例は肉眼的湾化がみられなかったが 細密検查の結果, 乳質も悪化し細菌も増殖して症状はも しろ不良となった.われわれは今までの慢性乳房焱の治 療に佂いて，この上うに治療後悪化したものに遭遇して いない. 他の細菌で in vitro で証明されているように 抗ぺ性となったぶ菌もオマ耐性とならないか，または極 めて耐性獲得は抢そい上うで，転換療法の 1 頭は in vivoに拈いてこれを裏書きするように思われた。 SLANETZ \& ALLEN ら13) もぺ剂治療化成功しなかった連菌 性乳房悠の転換療法としてオマ軟膏を試久て，その卓越
した効果を強調した．そこで今後乳房炎の治療について は，これらの点に考慮を払うことが肝要であうう。

この試験に打いてはマイシリンはストレプトマイシン が $0.5 \mathrm{~g}$ 混大しているものを用いたが，グラム陰性菌と の混合感染の拈それの強いような場合沈いては $1.0 \mathrm{~g}$ 混大のマイシリンを使用することも一洗で，マイシリン は普通の室温では少くとも 3 日間はその抗菌価変化が なく，7日で約 $10 \%$ 程度の抗菌力の低下方認められるに すぎないから，保存にわずかの注意を払うことによっ て, 初め使用する時に溶液として打いて子安心して治療 を行いらる。

\section{要 約}

1. オマ技よびマイシリンを用いぶ菌性乳房炎18頭, 42分房の治療試験を行った結果, いずれも慢性症に対し て相当の効果が期待できることを知った。

2. オマとマイシリン相互の転換療法は成績不良で， 症状の悪化することもあった。しかしへ剤它主とする療 法に失敗した分㚾前の 1 頭，4 分房の治療をオマにか光 て比較的優秀な薬効を認めた。

3. レダリー会社の乳房焂用のオマ軟高の乳房内注大 による乳中濃度を測定したが，高い濃度を長時間持続す ることができだ。同時に 1 頭については血中および尿中 濃度をるみたが，同様これらのうちにオマを比較的長時 間証明することができた。

4. 純粋酒醉分離することのできた1例の急性乳 房炎の治験例で記載した。この治療にはぺ剂とサルン゙ー ルSとの混注学行った。

ての試験に和いてレ・ダリー会社製乳房悠用オマ軟膏と 同社製オマ含有子㗬坐薬とを提供して下さった武田薬品 工業株式会社火感謝する。

\section{交 $\because$ 献}

1) COOPER, G. W. FORD, C. M. \& ROBINSON, G. R. North Am. Vet., 31, 656, (1950). 2) EASTERBROOKS, H.L.: J.A.V.M.A., 116, 48, (1950). 3) FOLEY, E. J. \& BRYNE. J. V. : Cornell Vet., 39. 243, (1949). 4) HULSE, E. C. : Vet. Rec.. 64, 210, (1952). 5) KLEIN, M. \& KIMMELMAN, I. J, J. Bact. 54, 8, (1947). FOLEY \& BRYNE から引用. 6) MeCOI. I.CH, E. C., KISER, J. S. \& MIGAKI, H. : Vet. Med., 44, 253,(1949). 7) MURPHY, J. M. \& DRAKE, C. H. : Am. J. Vet. Res., 8, 43. (1947), J. A. V. M. A., 110, 270. (1947). (Abst.) 8) POUNDEN. W. D. AMBERSON, J. M. \& JAEGER, R. F. : Am. J. Vet. Res., 13, 121, (1952). 9) SCHALM. O. W. : J. A. V. M. A., 117, 396, (1950). 10)—— WOODS, G. M. : Am. J. Vet. Res., 13, 26, (1952). 11) SCHIPPER, I. A. : North Am. Vet., 33, 474, (1952). 12) —\& PETERSEN, W. E. : Vet.Med., 47, 369,(1952). 13) SI.ANETZ, I. W. \& ALIEN, F. F.: J. A. V. M. A., 117, 392, (1950). 14) SPENCER, G. R.,KRAFT, M. E., SIMON, J. \& SCHENK, M. : $J$. A. V. M. A., 117, 414, (1950). 15) STUART, P. : Vet. Rec., 63,314,(1951), HULSE から引用. 16) 鳥居, 川上 : ペニシリン, 1, 281, (1947). 17) 鳥居, 小島: 同誌, 3, 526. (1950)。18) 吉田, 㭾 沢, 天野：日獣㙝会誌, 3.379, (1950). 19) 吉田, 天野. 今井：日 獣会誌, 4, 1, (1951). 20) 吉田, 天野, 桐沢：日獣会誌, 6, 155, (1953). 